\title{
The purification and some properties of rhodanese from tortoise (Kinixys erosa, Schweigger) liver
}

\author{
Omolara Titilayo ALADESANMI, Raphael Emuebie OKONJI * and Adenike KUKU \\ Department of Biochemistry, Obafemi Awolowo University, Ile-Ife, Nigeria. \\ *Corresponding author: E-mail: okonjire@yahoo.co.uk; reokonji@oauife.edu.ng; \\ Tel: +2348060164991 .
}

\begin{abstract}
Rhodanese (cyanide: thiosulphate sulphur transferase; EC.2.8.1.1) was isolated from cytosolic fraction of tortoise liver using ammonium sulphate fractionation, ion exchange chromatography and gel filtration from the liver of tortoise. The enzyme had a specific activity of $14.43 \mathrm{RU}$ per milligram of protein. The $\mathrm{K}_{\mathrm{m}}$ values for $\mathrm{KCN}$ and $\mathrm{Na}_{2} \mathrm{~S}_{2} \mathrm{O}_{3}$ were $16 \mathrm{mM}$ and $30.0 \mathrm{mM}$ respectively. The native and subunit molecular weight of the enzyme was found to be 33,000 and 35,000 dalton respectively. The optimum pH and temperature for the enzyme activity were 6.5 and $50{ }^{\circ} \mathrm{C}$ respectively. The enzyme was inhibited by $\mathrm{Ba}^{2+}$ and $\mathrm{Zn}^{2+}$ but not affected by $\mathrm{Mn}^{2+}, \mathrm{Co}^{2+}, \mathrm{Sn}^{2+}, \mathrm{Ni}^{2+}$ and $\mathrm{NH}_{4}{ }^{2+}$.

(C) 2009 International Formulae Group. All rights reserved.
\end{abstract}

Keywords: Rhodanese, tortoise, detoxification, sulphurtransferase enzyme, cyanide toxicity.

\section{INTRODUCTION}

The enzyme rhodanese (cyanide: thiosulphate sulphurtransferase; E.C.2.8.1.1) is a multifunctional sulphur transferase enzyme that is ubiquitous in nature (Westley, 1981; Agboola and Okonji, 2004; Aminlari et al., 2007; Akinsiku et al., 2009). Rhodanese catalyses the cyanide-dependent cleavage of thiosulphate to thiocyanate and sulphite in a double displacement (ping pong) mechanistic reaction (Blumenthal and Heinrikson, 1971; Westley, 1981; Nagahara et al., 1999). The enzyme originally found in the mitochondrion has now been reported to also be located in the cytosol and other organelles (Nagahara et al., 1999; Agboola and Okonji, 2004; Akinsiku et al., 2009). Its presence in the liver tissues of different animals has been demonstrated (Blumenthal and Heinrikson, 1971; Jarabak and Westley, 1974; Lee et al., 1995; Nazif et al., 2003; Agboola and Okonji, 2004; Akinsiku et al., 2009). However, its presence has also been shown in other tissues and/organs (Westley, 1981; Aminlari et al., 2007; Shahbazkia et al., 2009).

The enzyme has been purified and characterised from a number of animal tissues (Ploegman et al., 1978; Lee et al., 1995; Nagahara et al., 1998; Ali et al., 2001; Agboola and Okonji, 2004; Akinsiku et al., 2009). A well characterised rhodanese from bovine liver was found to be a single polypeptide chain of molecular weight 32,900 daltons and composed of 293 amino acids (Russell et al., 1978; Ploegman et al., 1978).

It is generally believed that the major function of rhodanese is cyanide detoxification (Smith and Urbanska, 1986; Buzaleh et al., 1990). This function is more prominent in mammals where highly cytotoxic cyanide is converted to a less toxic thiosulphate and excreted through the kidney (Lee et al., 1995; Nazif et al., 2003; Aminlari et al., 2007). However, some evidence had shown that the enzyme may be involved in other functions including formations of iron 
sulphur centres, participation in energy metabolism (Bonomi et al., 1977; Ogata and Volini, 1990) and also function as thioredoxin oxidase (Nandi et al., 2000). Matthias et al. (2004) proposed a physiological role of a rhodanese-like protein in the biosynthesis of molybdenum cofactor in humans.

The giant African land tortoise (Kinixys erosa Schweigger) is a herbivore belonging to the reptilia class and to the order testudines and the family of testudinidae (Bellairs, 1969; Webb et al., 1978). Different species of hinge-back tortoises are found in Africa. Two of these - Kinixys homeana and Kinixys erosa, are similar and are found in the same areas, in West, East and Central Africa (Bellairs, 1969; Webb et al., 1978). Both are forest dwellers, with Kinixys erosa preferring a moister environment. It is often found in marshes and on river banks and is a fair swimmer. Our aim therefore is to characterise rhodanese from liver of Kinixys erosa for the purpose of biochemical evolutionary comparison. Moreover, the animal feeds on all kinds of leafy vegetables some of which may be cyanogenic and presumably the detoxification mechanism of rhodanese would be in operation in the animal.

\section{MATERIALS AND METHODS Materials}

Trizma base, Trizma- $\mathrm{HCl}$, ethylenediamine tetraacetic acid (EDTA), DEAE Cellulose, CM-Cellulose and low molecular weight calibration kit for electrophoresis were purchased from Sigma Chemical Company, St. Louis, Mo, USA. Sucrose, sodium chloride, phosphoric acid, manganese chloride tetrahydrate, ethanol, methanol, ammonium sulphate, glacial acetic acid, were purchased from BDH Chemical Limited, Poole England. Potassium chloride, sodium dodecyl sulphate (SDS), acrylamide and N, N'-methylene bisacrylamide (MBA), ammonium persulphate, N,N,N',N'tetramethylenediamine (TEMED) and Sephadex G series, are from Pharmacia Fine Chemicals, Uppsala, Sweden. All other reagents are of analytical grade. Tortoises were purchased from a local market in Ile-Ife, Nigeria.

\section{Enzyme extraction and purification}

The lower carapace shell was cut open with a hand saw and the liver excised and stored in the refrigerator until required. The tissue was minced and then homogenised in a Warring Blender in nine volumes of the homogenisation buffer containing $0.25 \mathrm{M}$ sucrose in $0.01 \mathrm{M}$ Tris- $\mathrm{HCl}$ buffer, $\mathrm{pH} 7.5$ containing $0.01 \mathrm{M} \mathrm{MnCl}_{2}$. The homogenate obtained was stirred occasionally for one hour and then subjected to centrifugation at 6,000 rpm Beckman Optima LE-80K Ultracentrifuge for $30 \mathrm{~min}$. The supernatant was filtered using a double-layered cheese cloth and the precipitate was rehomogenised in 2 volumes of homogenisation buffer and centrifuged under the same condition. The supernatants were then pooled together and brought to $80 \%$ ammonium sulphate concentration, and left for $12 \mathrm{hr}$. The resulting precipitate was dialyzed against several changes of $50 \mathrm{mM}$ citrate buffer, $\mathrm{pH} 5.0$ containing $10 \mathrm{mM} \mathrm{Na} \mathrm{S}_{2} \mathrm{O}_{3}$. The dialysate was centrifuged at $6,000 \mathrm{rpm}$ for $30 \mathrm{~min}$ to remove insoluble material. This was used for the ion exchange step

The CM-Sephadex C50 cation exchanger resin was first pretreated and equilibrated according to the manufacturer's manual. The gel was packed into a 2.5 X 40 $\mathrm{cm}$ glass column. The enzyme fraction from the previous step was layered on it. Fractions of $5 \mathrm{ml}$ were collected from the column at the rate of $36 \mathrm{ml}$ per hour. The protein was monitored at $280 \mathrm{~nm}$. The fractions were also assayed for rhodanese activity. The fractions with high enzyme activities were pooled and preserved in $80 \%$ ammonium sulphate solution.

\section{Enzyme assay and protein concentration determination}

Rhodanese activity was measured during purification and routinely according to the method employed by Agboola and Okonji (2004) using $\mathrm{KCN}$ and $\mathrm{Na}_{2} \mathrm{~S}_{2} \mathrm{O}_{3}$ as substrates. The activity of the enzyme is expressed in Rhodanese unit (RU). One Rhodanese unit is taken as the amount of enzyme which under the given conditions will produce an optical density reading of 1.08 at $460 \mathrm{~nm}$.

Bradford method (1976) was used routinely to measure the protein concentration 
of the enzyme using bovine serum albumin (BSA) as a standard.

\section{Kinetic studies}

The $\mathrm{K}_{\mathrm{m}}$ and $\mathrm{V}_{\text {max }}$, were determined by varying the concentration of $\mathrm{KCN}$ (between $10 \mathrm{mM}$ and $70 \mathrm{mM}$ ) at fixed concentrations of $\mathrm{Na}_{2} \mathrm{~S}_{2} \mathrm{O}_{3}(50 \mathrm{mM})$ and also varying the concentration of $\mathrm{Na}_{2} \mathrm{~S}_{2} \mathrm{O}_{3}$ (between $50 \mathrm{mM}$ and $600 \mathrm{mM}$ ) at fixed concentrations of $\mathrm{KCN}$ $(50 \mathrm{mM})$. The kinetic parameters were then estimated from the double reciprocal plots.

\section{Effect of $\mathbf{p H}$}

The enzyme preparation above was desalted on a small column of Biogel P10 and assayed at, $\mathrm{pH}$ between 4 and 11 using $50 \mathrm{mM}$ citrate buffer ( $\mathrm{pH} 4.0-6.5), 50 \mathrm{mM}$ phosphate buffer (pH 7.0-8.0) and $50 \mathrm{mM}$ borate buffer $(\mathrm{pH} 8.5-11.0) .1 \mathrm{ml}$ of the assay mixture contained $0.1 \mathrm{M}$ of the required buffer, 0.05 $\mathrm{M}$ KCN, $0.05 \mathrm{M} \mathrm{Na}_{2} \mathrm{~S}_{2} \mathrm{O}_{3}$ and $20 \mu \mathrm{l}$ of the enzyme solution.

\section{Effect of temperature}

The enzyme $(20 \mu \mathrm{l} ; 1.15 \mathrm{mg} / \mathrm{ml})$ was assayed at temperatures between $30^{\circ} \mathrm{C}$ and 70 ${ }^{\circ} \mathrm{C}$ to investigate the effect of temperature on the activity of the enzyme. The assay mixture was first incubated at the indicated temperature for $10 \mathrm{~min}$ before the addition of a $20 \mu \mathrm{l}$ aliquot of the enzyme.

\section{Effect of cations}

The effect of the following salts nickel chloride, ammonium chloride, tin chloride, manganese chloride, colbat chloride, barium chloride and zinc chloride on the activity of rhodanese was investigated by assaying the enzyme at $0.5 \mathrm{mM}$ and $1.0 \mathrm{mM}$ final salt concentrations in the reaction mixture.

\section{Native Molecular Weight Determination}

The native molecular weight was determined on a calibrated Biogel-P 200 column $(2.5 \times 100 \mathrm{~cm})$. The standard proteins were gamma-globulin: $150,000 \mathrm{da}$; creatinine phosphokinase (CPK): 81,000 da; BSA: 66,000 da; ovine albumin: 45,000 da; alphachymotrypsinogen A: 25,000 da. In calibrating the column, $5 \mathrm{ml}$ of each standard of $5 \mathrm{mg} / \mathrm{ml}$ was applied to the column separately. The column was eluted at a flow rate of $10 \mathrm{ml} / \mathrm{h}$ with a $5 \mathrm{mM}$ tris- $\mathrm{HCl}$ buffer,
$\mathrm{pH}$ 7.2. Fractions of $4 \mathrm{ml}$ were collected and monitored for protein at $280 \mathrm{~nm}$. The void volume $\left(\mathrm{V}_{\mathrm{o}}\right)$ of the column was determined by the elution volume of Blue Dextran.

$\begin{array}{llrr}\begin{array}{l}\text { Determination of } \\ \text { Weight }\end{array} \text { Subunit } & \text { Molecular } \\ \text { Sodium } & \text { dodecyl } & \text { sulphate }\end{array}$
polyacrilamide gel electrophoresis (SDSPAGE) was performed, for ascertaining the purity of the preparation in accordance with the procedure of Weber and Osborn (1975) on $10 \%$ rod gels using the phosphate buffer system. The sample preparation, application and running conditions were performed according to Weber and Osborn (1975) instruction.

The standard proteins were as contained in Sigma Molecular Weight Markers Calibration Kit for SDSpolyacrilamide gel electrophoresis (Daltons Mark VII -L, low molecular weight marker range 14,000-67,000).

\section{RESULTS \\ Purification of Rhodanese}

The results of the purification of rhodanese from the liver of tortoise are summarized in Table 1. The elution profile after CM-Sephadex ion-exchange chromatography is shown in Figure 1. Only one activity peak was obtained.

\section{Kinetic parameters}

Figures 2 and 3 show the Lineweaver-Burk plots for fixed concentration of thiosulphate and $\mathrm{KCN}$ respectively. The $\mathrm{K}_{\mathrm{m}}$ values for $\mathrm{KCN}$ and $\mathrm{Na}_{2} \mathrm{~S}_{2} \mathrm{O}_{3}$ were $16.8 \mathrm{mM}$ and $30.3 \mathrm{mM}$ respectively while the $\mathrm{V}_{\max }$ values for the two substrates $(\mathrm{KCN}$ and $\mathrm{Na}_{2} \mathrm{~S}_{2} \mathrm{O}_{3}$ ) were 5.0 and 20.2 respectively.

\section{Effects of pH and temperature on enzyme activity}

There was an increase in the enzyme activity between $\mathrm{pH} 7.0$ and 8.5. An optimum $\mathrm{pH}$ was observed at $\mathrm{pH} 8.5$ while the activity of the enzyme decreased between $\mathrm{pH} 9.0$ and pH 11.0 as shown in Figure 4. The optimum temperature was $50{ }^{\circ} \mathrm{C}$ (Figure 5).

\section{Effects of cations}

The results of the effect of various cations on the activity of the enzyme showed that $\mathrm{Mn}^{2+}, \mathrm{Co}^{2+}, \mathrm{Sn}^{2+}$ while $\mathrm{NH}_{4}^{+}$had little or 
Table 1: Summary of the purification of Rhodanese from the tortoise liver.

\begin{tabular}{lcccccc}
\hline Fractions & $\begin{array}{l}\text { Volume } \\
(\mathbf{m l})\end{array}$ & $\begin{array}{l}\text { Total } \\
\text { Protein } \\
(\mathbf{m g})\end{array}$ & $\begin{array}{l}\text { Total } \\
\text { Activity } \\
(\mathbf{R U})\end{array}$ & $\begin{array}{l}\text { Specific } \\
\text { Activity } \\
(\mathbf{R U} / \mathbf{m g})\end{array}$ & $\begin{array}{l}\text { Purification } \\
\text { fold }\end{array}$ & $\begin{array}{c}\text { YIELD } \\
(\%)\end{array}$ \\
\hline Crude Extract & 170 & $4,590.00$ & $17,787.04$ & 3.88 & 1.00 & 100.00 \\
\hline $\begin{array}{l}80 \% \text { Ammonium } \\
\text { sulphate precipitate }\end{array}$ & 240 & 686.40 & $6,711.12$ & 9.78 & 2.52 & 37.70 \\
\hline $\begin{array}{l}\text { CM-Sephadex ion- } \\
\text { exchange } \\
\text { chromatography }\end{array}$ & 55 & 150.54 & $2,172.29$ & 14.43 & 3.72 & 12.20 \\
\hline
\end{tabular}

Each step was carried out as described in the text. Protein concentration was determined by Bradford method. One unit of enzyme activity is the amount of the enzyme that will produce an optical density reading of 1.08 at $460 \mathrm{~nm}$ per min under a given condition (Sorbo, 1951).

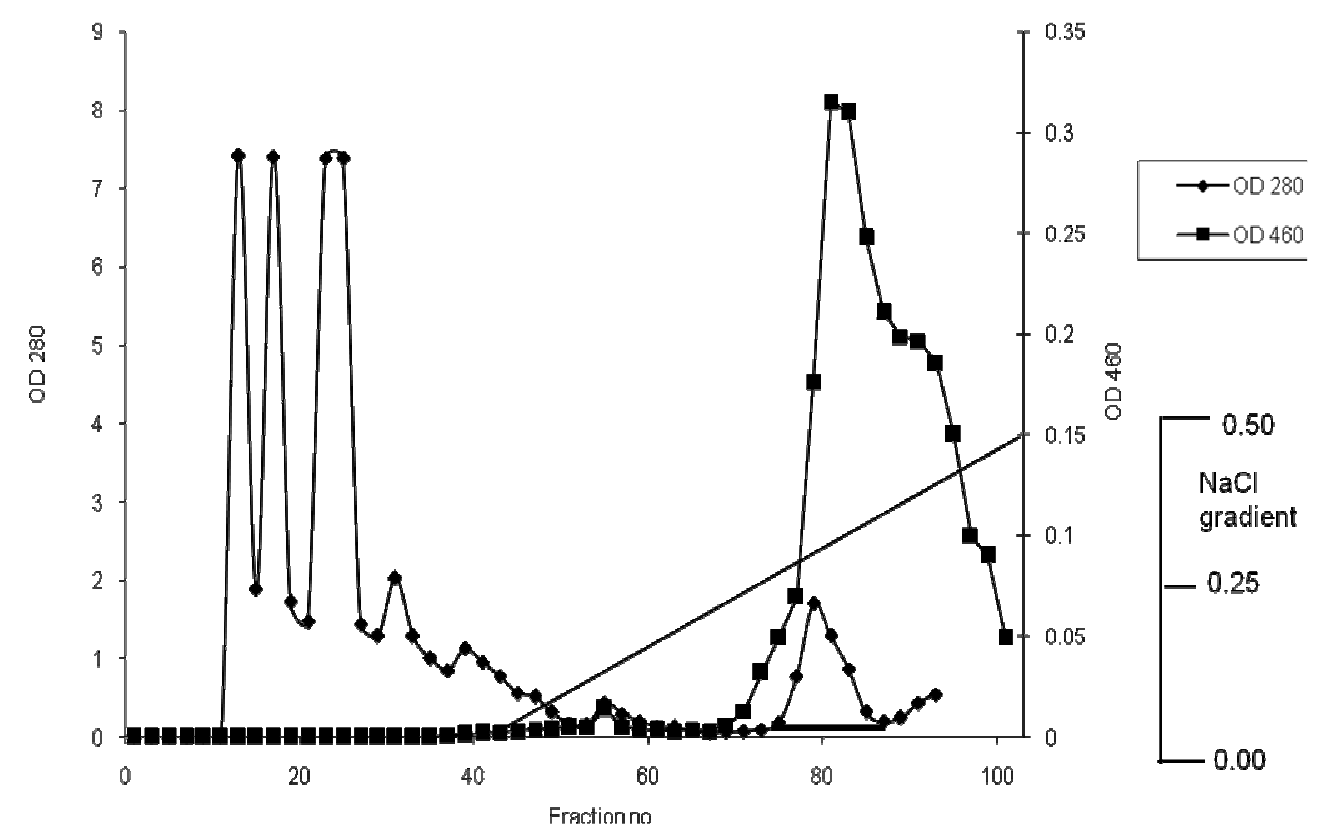

Figure 1: CM-Sephadex C-50 ion-exchange chromatography. The column was first washed with $300 \mathrm{ml}$ of citrate buffer, $\mathrm{pH} 5.0$, containing $10 \mathrm{mM}$ sodium thiosulphate. The column was then eluted with $400 \mathrm{ml}$ linear gradient of 0-5 $\mathrm{M} \mathrm{NaCl}$ at a flow rate of $36 \mathrm{ml} / \mathrm{hr}$. Fractions of $5 \mathrm{ml}$ were collected. Pooled fractions (

no effect on the enzyme activity. However, both concentrations $(0.5 \mathrm{mM}$ and $1.0 \mathrm{mM})$ of $\mathrm{Ba}^{2+}, \mathrm{Zn}^{2+}$ and $\mathrm{Ni}^{2+}$ inhibited the enzyme considerably as seen in Table 2 .

\section{DISCUSSION}

The land tortoise (Kinixys erosa, Schweigger) consumes a wide range of leafy vegetables, many of which are known to contain cyanogenic glycosides (Thomsen and Brimer, 1997; Conn, 2008). It is therefore reasonable for us to assume that the animal possesses a good and efficient cyanide detoxifying mechanism.

This work demonstrated the presence of rhodanese in the liver of the tortoise. Rhodanese was isolated and purified near homogeneity from the liver of the land 


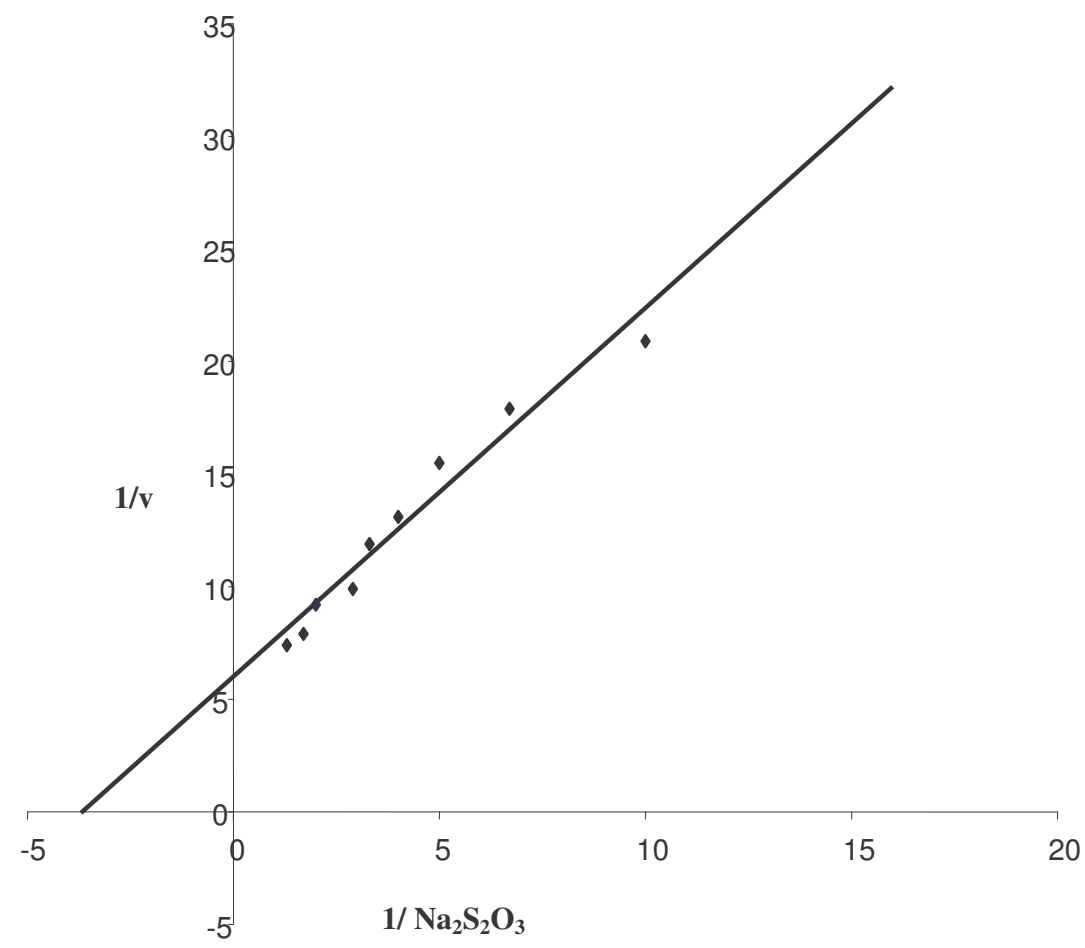

Figure 2: Lineweaver-Burk plot for the determination of the kinetic parameters of $\mathrm{Na}_{2} \mathrm{~S}_{2} \mathrm{O}_{3}$ at fixed concentrations of KCN. Enzyme was assayed at varying concentrations of $\mathrm{Na}_{2} \mathrm{~S}_{2} \mathrm{O}_{3}$ at $50 \mathrm{mM} \mathrm{KCN}$.

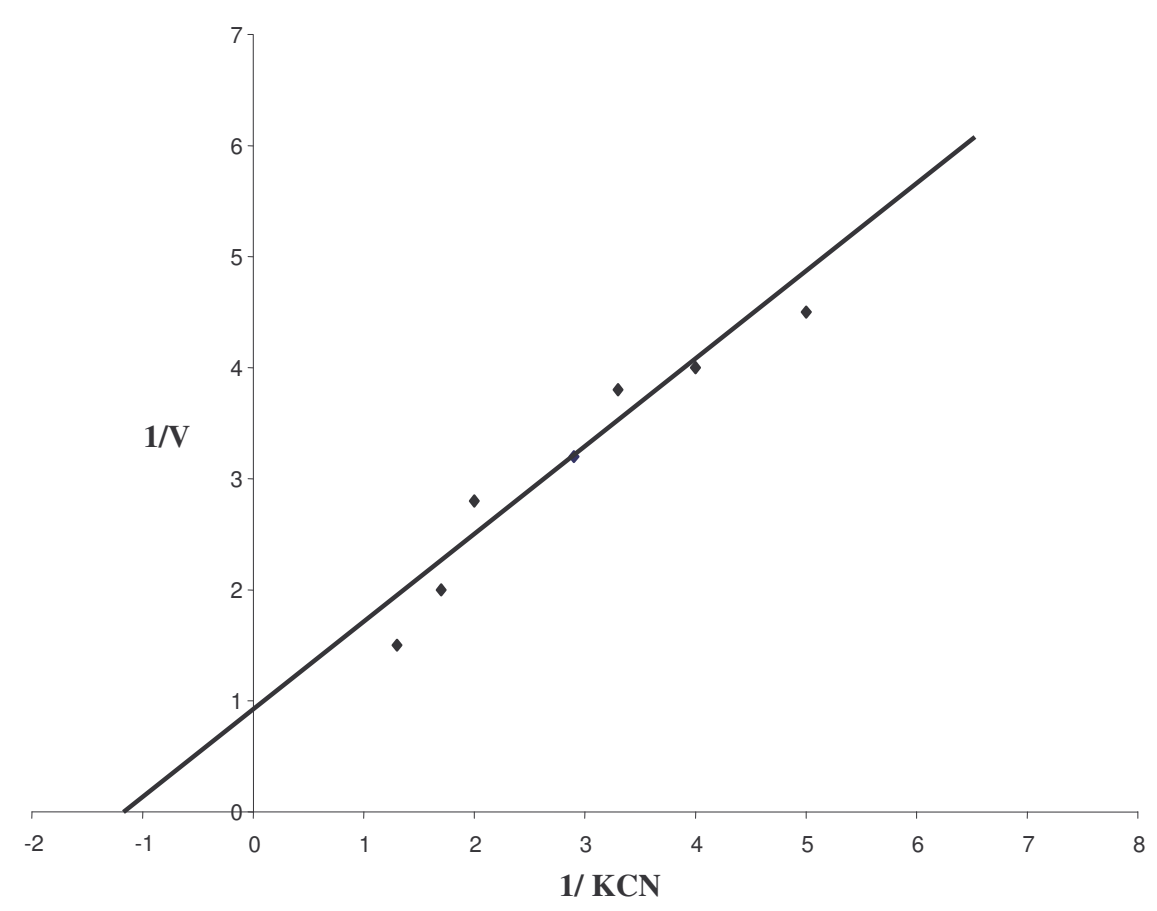

Figure 3: Lineweaver-Burk plot for the determination of the kinetic parameters of $\mathrm{KCN}$ at fixed concentrations of $\mathrm{Na}_{2} \mathrm{~S}_{2} \mathrm{O}_{3}$. Enzyme was assayed at varying concentrations of $\mathrm{KCN}$ at $50 \mathrm{mM} \mathrm{Na} \mathrm{S}_{2} \mathrm{O}_{3}$. 


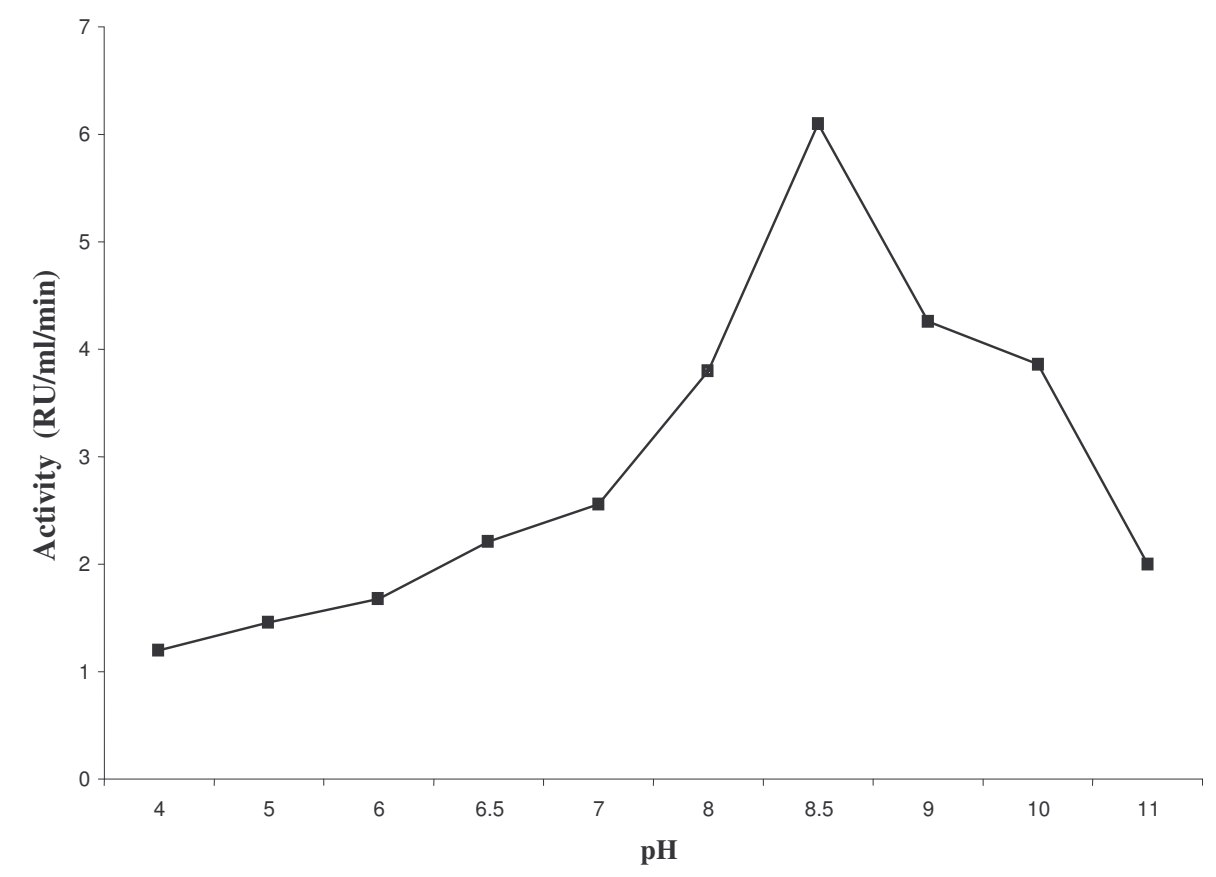

Figure 4: Effect of $\mathrm{pH}$ on rhodanese activity from the tortoise liver. The assay mixture contained $0.1 \mathrm{M}$ of buffer, $0.05 \mathrm{M} \mathrm{KCN}, 0.05 \mathrm{M} \mathrm{Na}_{2} \mathrm{~S}_{2} \mathrm{O}_{3}, 20 \mu$ of the enzyme solution in a final volume of $1.0 \mathrm{ml}$.

Table 2: Effects of cations on the activity of rhodanese from the liver of tortoise.

\begin{tabular}{|c|c|c|}
\hline & \% Enzyme residual activity & $\%$ Enzyme residual activity \\
\hline SALT & $250 \mu \mathrm{M}$ & $500 \mu \mathrm{M}$ \\
\hline NONE & 100 & 100 \\
\hline $\mathrm{ZnCl}_{2}$ & 38 & 41 \\
\hline $\mathrm{MnCl}_{2}$ & 80 & 82 \\
\hline $\mathrm{CoCl}_{2}$ & 85 & 89 \\
\hline $\mathrm{BaCl}_{2}$ & 32 & 36 \\
\hline $\mathrm{NH}_{4} \mathrm{Cl}$ & 82 & 84 \\
\hline $\mathrm{NiCl}_{2}$ & 56 & 58 \\
\hline $\mathrm{SnCl}_{2}$ & 76 & 72 \\
\hline
\end{tabular}

Enzyme assay was carried out using the standard assay procedure with the salts having final concentrations of $250 \mu \mathrm{M}$ and $500 \mu \mathrm{M}$. The values are average of three determinations.

tortoise using ammonium sulphate precipitation and CM-Sephadex ion exchange chromatography.

The results showed the specific activity of rhodanese from the liver of the land tortoise to be $14.43 \mathrm{RU} / \mathrm{mg}$. Different values were obtained for rhodanese using different preparations and methods. Sorbo (1953 a) working on bovine liver rhodanese obtained a value of $256 \mathrm{RU} / \mathrm{mg}$. Lee et al. (1995) reported a value of $1,076 \mathrm{RU} / \mathrm{mg}$ for rhodanese from the mouse liver. Agboola and Okonji (2004) also reported a value of 131 $\mathrm{RU} / \mathrm{mg}$ for rhodanese from the fruit bat liver. Akinsiku et al. (2009) obtained low values of 73 and 72 RU/mg for catfish liver rhodanese I 


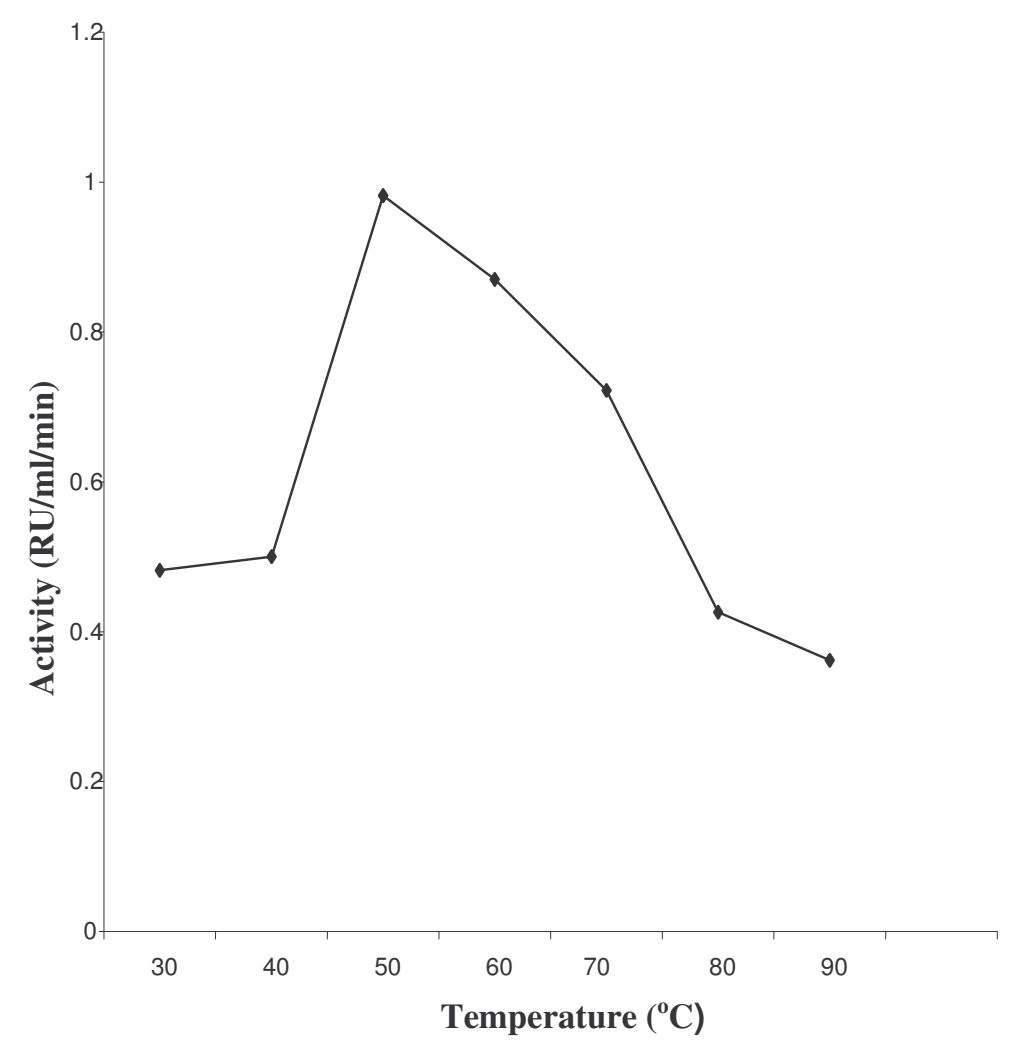

Figure 5: The activity-temperature profile indicating the optimum temperature. $20 \mu 1$ aliquot of enzyme was assayed at temperature between $0{ }^{\circ} \mathrm{C}$ and $70{ }^{\circ} \mathrm{C}$ to investigate the effect of temperature on the activity of the enzyme. The assay mixture was first incubated at the indicated temperature for $10 \mathrm{~min}$ before initiating the reaction by the addition of the enzyme.

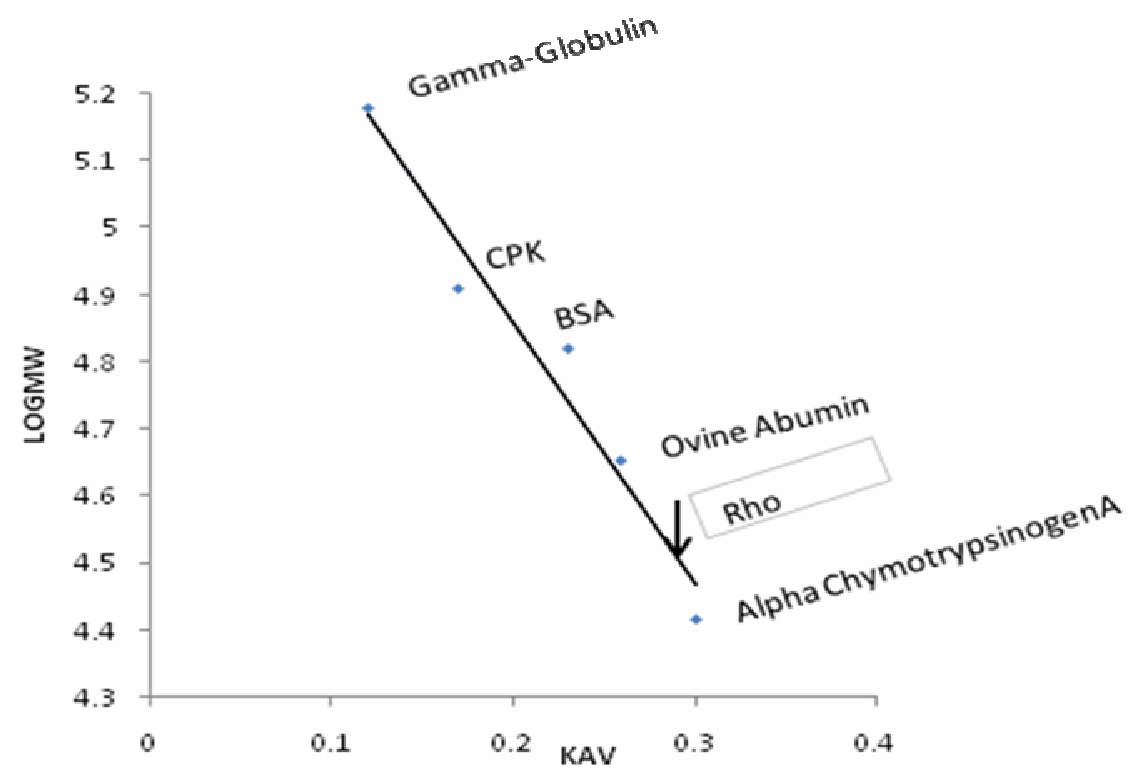

Figure 6: Calibration curve for the determination of native molecular weight of the tortoise liver rhodanese using Biogel-P200. The procedure is as described in the text. The standard proteins used includes gamma globulin: 150,000 da; creatinine phosphokinase (CPK): 81,000 da; BSA: 66,100 da; ovine albumin: 45,000 da; alphachymotrypsinogen A: 25,000 da. Rhodanese from tortoise liver is shown in the box. 


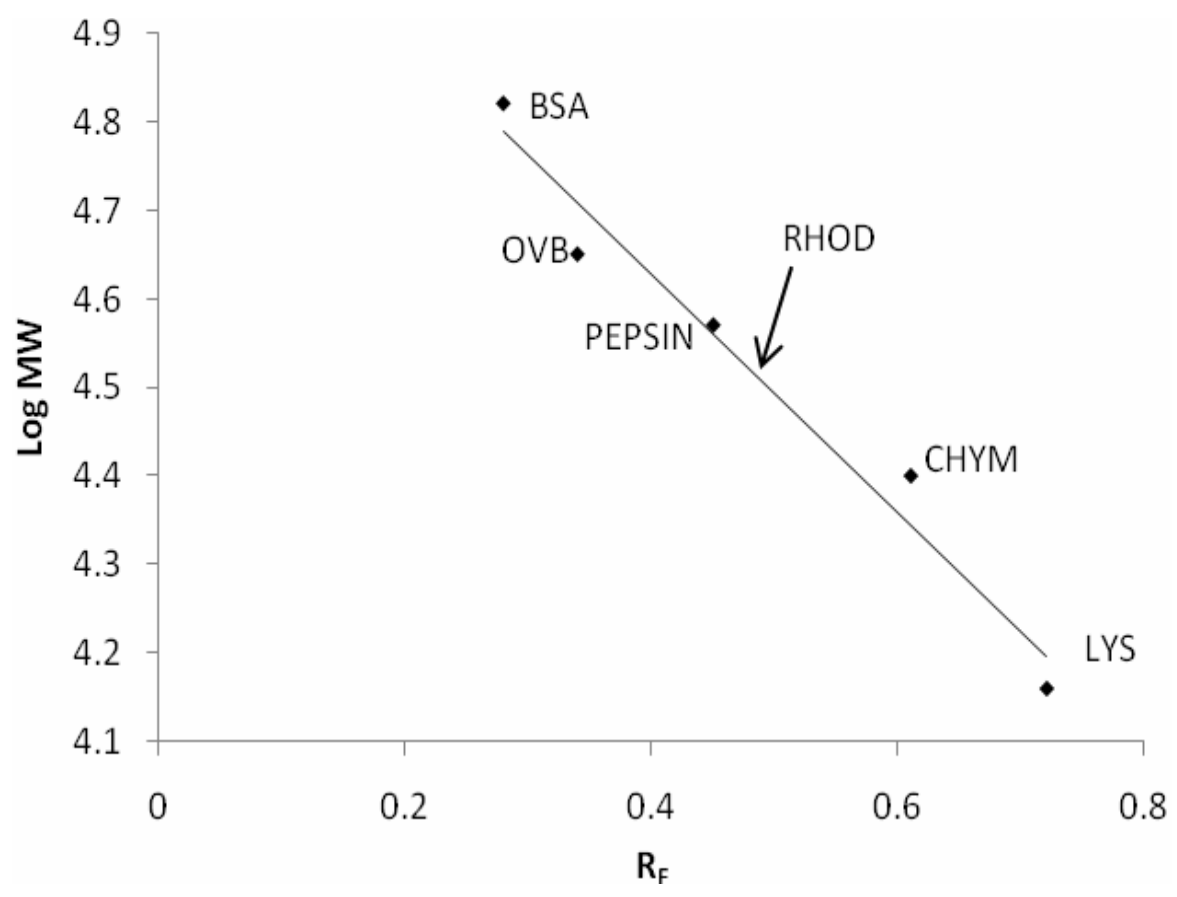

Figure 7: Calibration curve for the determination of subunit molecular weight of the tortoise liver rhodanese using SDS-PAGE. The procedure is as described in the text. The standard proteins were as contained in Sigma Molecular Weight Markers Calibration Kit for SDS-polyacrilamide gel electrophoresis (Daltons Mark VII -L, low molecular weight marker range 14,000-67,000). BSA (Bovine Serum Albumin :66,000dalton), OVB (Ovalbumin: 45,000 dalton), Pepsin: 37,000 dalton), CHYM (Chymotrypsinogen A: 25,000 dalton) and LYS (Lysozyme: 14,5000 dalton). Rhodanese from tortoise liver (RHOD) is represented with arrow line.

and II respectively. The low specific activity obtained in this work may have been due in part to a step in our preparations and possibly the source of the enzyme.

The native molecular weight of tortoise liver rhodanese was 33,000 dalton as estimated by gel filtration with a subunit molecular weight of 35,000 dalton estimated by SDS-PAGE (this showed that the enzyme is not a dimer). This native molecular weight is similar to those of the enzyme from other sources: fruit bat liver $(36,400$ dalton; Agboola and Okonji, 2004), bovine liver (37,000 dalton; Sorbo, 1953a,b), human liver (37,000 dalton, Jarabak and Westley, 1974) and mouse liver $(34,800$ dalton; Lee et al., 1995). The molecular weight and number of polypeptides in rhodanese has been a subject of controversy. Since Sorbo (1953a) initially reported a molecular weight of 37,000 dalton for rhodanese, numerous investigators have suggested an approximate molecular weight value of 33,000 to 37,000 dalton for rhodanese and a dimer composed of two identical subunits with molecular weight range of 18,000 to 19,000 dalton (Blumenthal and Heinrikson, 1971).

The $\mathrm{pH}$ optimum of 8.5 was obtained for rhodanese from the liver of land tortoise. Most reports have shown a $\mathrm{pH}$ range of 8.011.5 (Chew and Boey, 1971; Lee et al. 1995; Agboola and Okonji 2004). Kurban and Horowitz (1991) showed that at low pH (pH 4-6), rhodanese is stabilized against inactivation processes.

Various optimum temperatures have been reported for the enzymes from different sources.

An optimum temperature of $50{ }^{\circ} \mathrm{C}$ was obtained for land tortoise liver rhodanese. Sorbo (1953b) and Chew and Boey (1971) obtained optimum temperatures between $50^{\circ} \mathrm{C}$ and $59{ }^{\circ} \mathrm{C}$ for the bovine liver rhodanese and tapioca leaf rhodanese respectively. Agboola 
and Okonji (2004) also reported an optimum of $35{ }^{\circ} \mathrm{C}$ for the fruit bat liver rhodanese. As poikilothermic animals, tortoises need warmth to become active (Bourn, 1977; Chambers, 2004).

The kinetic parameters $\left(\mathrm{K}_{\mathrm{m}}\right.$ and $\left.\mathrm{V}_{\max }\right)$ for rhodanese from the liver of the land tortoise were obtained from the double reciprocal plots. The $\mathrm{K}_{\mathrm{m}}$ values for $\mathrm{KCN}$ and $\mathrm{Na}_{2} \mathrm{~S}_{2} \mathrm{O}_{3}$ were $16.83 \mathrm{mM}$ and $30.3 \mathrm{mM}$ respectively. These values are similar to those obtained from some other animal sources: bovine liver (19.0 and 6.7; Sorbo, 1953b), human liver (9.5 and 4.5; Jarabak and Westley, 1974), Mouse liver (12.5 and 8.3; Lee et al., 1995), and fruit bat liver (13.5 and 19.15; Agboola and Okonji, 2004). However, it is noted that the $\mathrm{K}_{\mathrm{m}}$ value $\left(\mathrm{Na}_{2} \mathrm{~S}_{2} \mathrm{O}_{3}\right)$ for tortoise liver rhodanese was higher than those of the mouse liver and bovine liver rhodaneses (8.3 $\mathrm{mM}$ and $6.7 \mathrm{mM}$ respectively). This shows that rhodanese from the liver of the land tortoise has a lower affinity for thiosulphate when compared to both the bovine liver rhodanese and the mouse liver rhodanese. These kinetic parameters obtained would allow the enzyme to function in the conversion of cyanide to thiosulphate to a less toxic thiocyanate in its environment, thereby improving the survival of the reptile.

Inhibition studies on the land tortoise liver rhodanese showed that the activity of the enzyme was not affected by $\mathrm{Mn}^{2+}, \mathrm{Co}^{2+}, \mathrm{Sn}^{2+}$, $\mathrm{Ni}^{2+}$ and $\mathrm{NH}_{4}^{+}$, while $\mathrm{Ba}^{2+}$ and $\mathrm{Zn}^{2+}$ inhibited the enzyme. This finding is also supported by the report of Nok et al. (1993) on the modulation of rhodanese activity by $\mathrm{Cu}^{2+}$, $\mathrm{Zn}^{2+}, \mathrm{Ca}^{2+}$ and Agboola and Okonji (2004), on the fruit bat liver rhodanese. The inhibitory effect of both $\mathrm{Ba}^{2+}$ and $\mathrm{Zn}^{2+}$ on rhodanese from the liver of land tortoise may be as a result of the interaction of these metal ions with the sulphydryl groups of the enzyme's catalytic site (Ulmer and Vallee, 1972, Nagahara et al., 1999). Inhibition by salts and certain monovalent anions may be due in part, to an increase in the ionic strength of the medium (Mintel and Westley, 1966). Some metal ions with strong affinity for ligands (such as phosphate cysteinyl and histidyl side chains of protein) have been reported to inhibit rhodanese activity considerably (Ulmer and Vallee, 1972).

\section{REFERENCES}

Agboola FK, Okonji RE. 2004. Presence of rhodanese in the cytosolic fraction of the fruit bat (Eidolon helvum) liver. $J$. Biochem. Mol. Biol., 37(33): 275-281.

Ali A, AL-Qarawi Hassan M, Mousa BH. 2001: Tissue and intracellular distribution of Rhodanese and mercaptoethanol sulphurtransferase in ruminants and birds. Vet. Res., 32: 63-70.

Akinsiku OT, Agboola FK, Kuku A, Afolayan A. 2009. Physicochemical and kinetic characteristics of rhodanese from the liver of African catfish Clarias gariepinus Burchell in Asejire lake. Fish Physiol Biochem. DOI 10.1007/s10695-0099328-4.

Aminlari M, Malekhusseini A, Akrami F, Ebrahimnejad H. 2007. Cyanidemetabolizing enzyme rhodanese in human tissues: comparison with domestic animals. Comp. Clin. Pathol., 16(1): 4751.

Bellairs A. 1969. The Life of Reptiles (Vol. II). Weidnfeld and Nicolson: London; 1968.

Blumenthal KM, Heinrikson RL. 1971, Structural Studies of Bovine Liver Rhodanese: $1 . \quad$ Isolation and Characterization of two Active Forms of the Enzymes. J. Biol. Chem., 246(8): 2430-2437.

Bourn D. 1977. Reproductive study of giant tortoise on Aldabara. J. Zoo., 182: 27-38.

Bradford KM. 1976. A rapid and sensitive method for the quantitation of micrograme quantities of protein utilizing the principle of protein-dye binding. Anal. Biochem., 72: 248-254.

Buzaleh AM, Vazquez ES, Battle AMD. 1990. The effect of cyanide intoxication on hepatic rhodanese kinetics. Gen. Pharmacol., 21(2): 219 - 222.

Chambers PA. 2004. Sheltered live. In The Unexpected History of the Giant Tortoise. John Murray Publisher: London; 114-168

Chew MY, Boey CG. 1971. Rhodanese of tapioca leaf. Phytochem., 11: 167- 169.

Conn EE. 2008. Our work with cyanogenic plants. Ann. Rev. Plant Biol., 59: 1-19

Jarabak R, Westly J. 1974. Human liver rhodanese: non-linear kinetic behavior in a double displacement mechanism. Biochem., 13: 3233-3236. 
Kurban GP, Horowizt PM. 1991. Purification of bovine rhodanese by low $\mathrm{pH}$ column chromatography. Protein Exp. Purif., 2: 379-384.

Lee CH, Hwang JH, Lee YS, Cho KS. 1995. Purification and characterization of mouse liver rhodanese. J. Biochem. Mol. Biol., 28: 170-176.

Lineweaver H, Burk D. 1934. The determination of enzyme dissociation constant. J. Amer. Chem. Soc., 5: 658666.

Matthies A, Rajagopalan KV, Mendel RR, Leimkühler S. 2004. Evidence for the physiological role of a rhodanese-like protein for the biosynthesis of the molybdenum cofactor in humans. Proc. Nat. Acad. Sci., 101(16): 5946-5951.

Mintel R, Westley J. 1966. The rhodanese reaction. Mechanism of sulphur-sulphur bond cleavage. J. Biol. Chem., 241(14): 3381-3385.

Nagahara N, Ito T, Minam M. 1999. Mercaptopyruvate sulphuretransferase as a defence against cyanide toxications. Molecular properties and mode of detoxification. Histol. Histopath., 14: 277-1286.

Nandi DL, Horowitz PM, Westley J. 2000. Rhodanese as a thioredoxin oxidase. Int. J. Biochem. Cell Biol., 32(4): 465-473.

Nazif S, Aminlari M, Alaibakhsh MA. 2003. Distribution of rhodanese in tissues of goat (Capra hircus). Comp. Biochem. Phys. B., 134(3): 515-518.

Nok AJ, Nasir SM, Sa Adatu Y.1993.Immobilized rhodanese: some aspects of anion inhibition kinetics and modulation by cations. J. Biochem. Toxicol., 8(2): 57-62.

Ogata K, Volini M. 1990. Mitochondrial rhodanese: membrane bound and complex activity. J Biol Chem., 265: 8087-8093.

Ploegman JH, Drent G, Kalk KH, Hol WG. 1978. Structure of bovine liver rhodanese. I. Structure determination at $2.5 \AA$ resolution and a comparison of the conformation and sequence of its two domains. J. Mol. Biol., 123: 557-594.

Russell J, Weng L, Keim PS, Heinrikson RL. 1978. The covalent structure of bovine liver rhodanese. J. Biol. Chem., 253: 8102-8108.

Shahbazkia HR, Aminlari M, Tavana M. 2009. Distribution of the enzyme rhodanese in tissues of the cat (Felis catus). J. Fel Med Surg. 11(4): 305-308.

Smith J, Urbanska KM. 1986. Rhodanese activity in Lotus corniculatus J. Nat. Histol., 20(6): $1467-1476$.

Sorbo BH. 1953a. Crystalline rhodanese. Acta. Chem. Scand., 7: 1129-1136.

Sorbo BH. 1953b. Crystalline rhodanese. Enzyme catalysed reaction Acta. Chem. Scand., 7: 1137-1145.

Thomsen K, Brimer L. 1997. Cyanogenic constituents in woody plants in natural lowland rain forest in Costa Rica. Bot. J. Linn. Soc., 124(3): 273-294.

Ulmer DD, Vallee BL. 1972. Role of metals in sulphurtranferases activity. Ann. Rev. Biochem. 32: 86-90.

Wang SF, Volini M. 1968. Studies on the active site of rhodanese J. Biol. Chem., 243: 5465- 5470.

Webb JE, Wallwork JA, Elgood JT. 1978. Turtle and Tortoise: In Guide to Living Reptiles. Macmillan Press Ltd.: London; 38-63.

Weber K, Osborn M. 1975. Protein and Sodium dodecyl sulphate: Molecular weight determination on polyacrylamide gel and related procedures. In The Proteins (vol. I), Neutrath H, Hill RL (eds). Academic Press: New York; 179223.

Westley J. 1981. Cyanide and sulfane sulphur. In Cyanide in Biology. Vennesland $\mathrm{B}$, Conn EE, Knowles CJ, Westley J, Wissing $\mathrm{F}$ (eds). Academic Press: NewYork; 61-76.

Wokes F, Willimott SG. 1951. The determination of cyanide in seed. $J$. Pharm. Pharmacol., 3: 905-916. 